\title{
PERADILAN BERBASIS HARMONI DALAM DALAM GUYUB BUDAYA LAMAHOLOT - FLORES*
}

\author{
Karolus Kopong Medan \\ Fakultas Hukum Universitas Nusa Cendana Kupang \\ E-mail : komed2001@yahoo.com
}

\begin{abstract}
This study tried to offer a new theoretic perspective about settlement form of criminal case. Through law anthropolgy study by using etnography approach and hermeneutic analysis method, this study more strengthen the faith that the final goal of every court process is not only to determine who is wrong and who is right, but also to find out the justice and the truth. But, additionally judicial process has to make a harmony or rebuild a social relation among the victims of conflict. Even, a social harmony that was built is managed generally as individual, and collective context, and as also vertically to the Almighty God. The judicial orientation with rich philosophy of harmony can be applied to social sphere, because actually the harmony value is everybody's dream in the world.
\end{abstract}

Key words: judicial, criminal, harmony, adat tradition, Lamaholot society.

\begin{abstract}
Abstrak
Kajian ini mencoba menawarkan sebuah wawasan teoretik baru tentang pola penyelesaian kasus kriminal. Melalui studi antropologi hukum dengan menggunakan pendekatan etnografis dan metode analisis hermeneutika, studi ini semakin memperkuat keyakinan bahwa sasaran akhir dari setiap proses peradilan tidak hanya untuk menentukan siapa yang salah dan siapa yang benar atau pun juga tidak hanya menemukan kebenaran dan keadilan. Melainkan, lebih jauh dari itu proses peradilan harus sedapat mungkin mendamaikan atau membangun kembali relasi sosial para pihak yang rusak sebagai akibat dari pertikaian. Bahkan, harmoni sosial yang dibangun itu dikelola dalam konteks yang lebih luas, baik secara individual, kolektif, dan secara vertikal dengan Sang Ilahi. Orientasi peradilan yang sarat dengan filosofi harmoni itu tampaknya dapat diterapkan dalam berbagai ruang sosial, karena nilai harmoni itu sesungguhnya merupakan dambaan dari semua manusia di belahan dunia mana pun.
\end{abstract}

Kata Kunci: peradilan, kriminal, harmoni, tradiasi adat, masyarakat Lamaholot.

\section{Pendahuluan}

Dewasa ini institusi peradilan yang ditetapkan oleh negara sebagai institusi resmi dalam menyelesaian berbagai kasus sengketa yang dihadapi oleh masyarakat sudah mulai diragukan keterandalan dan kesahihannya. Keraguan itu semakin mengemuka karena institusi pera-

\footnotetext{
- Tulisan ini merupakan sari dari Penelitian Hibah Kompetensi tahun I \& II(2010, 2011) berjudul “Menuju Model Peradilan Berbasis Harmoni dalam Penyelesaian Kasus Kriminal Menurut Tradisi Masyarakat Lamaholot di Flores Bagian Timur". Penelitian ini merupakan pengembangan lebih Ianjut dari Disertasi berjudul "Peradilan Rekonsiliatif: Konstruksi Penyelesaian Kasus Kriminal Menurut Tradisi Masyarakat Lamaholot di Flores, Nusa Tenggara Timur (NTT)" di PDIH Undip Semarang tahun 2006 di bawah Promotor Prof.Dr. Satjipto Rahardjo, S.H., dan Prof.Dr. Esmy Warassih, S.H,M.S.
}

dilan negara ini belum sepenuhnya menyentuh esensi yang sesungguhnya dari suatu proses hukum yang berorientasi pada perwujudan perdamaian di antara para pihak, termasuk antara (para) pelaku dengan (para) korban beserta seluruh keluarganya. Kebanyakan orang lebih berpikir bahwa dengan adanya keadilan diputuskan oleh hakim dan dilanjutkan dengan proses eksekusi maka dianggap sudah selesai urusannya. Proses hukum yang demikian itu justru masih menyimpan suatu dendam kusumat yang sewaktu-waktu bakal muncul, bahkan mungkin sema- 
kin kompleks dan memperburuk hubungan sosial di antara mereka. ${ }^{1}$

Persoalan substansial yang lain yang melatari tulisan ini adalah bahwa sekalipun peradilan negara sudah ditetapkan sebagai wadah resmi untuk menyelesaikan sengketa yang dihadapi oleh masyarakat, namun tidak menutup kemungkinan bagi masyarakat di tingkat lokal untuk menyelesaikan sengketanya melalui wadah peradilan adat yang dikemas mengikuti tradisi masing-masing daerah (kelompok suku). Bahkan, terkadang pula terjadi perpaduan antara kedua pola tersebut, baik dilakukan secara terang-terangan maupun secara diam-diam dalam praktik penanganan kasus sengketa.

Suatu hal yang patut dicermati dalam proses penanganan kasus sengketa, termasuk kasus kriminal di tingkat lokal adalah soal bagaimana pola-pola peradilan yang dikemas menurut tradisi masyarakat lokal mampu membangun harmonisasi di antara para pihak yang bertikai (berperkara). Persoalan ini semakin menarik untuk dikaji ketika ditemukan bahwa ternyata pada masyarakat yang masih bersahaja seperti masyarakat Lamaholot di Flores Provinsi Nusa Tenggara Timur (NTT) memiliki tradisi perdamaian yang dikemas dalam ritual adat mela sare atau tapan holo. ${ }^{2}$ Tradisi perdamaian ini tampaknya merupakan salah satu "kunci" bagi masyarakat Lamaholot untuk

\footnotetext{
Tragedi pengrusakan gedung Pengadilan Negeri Ruteng dan penikaman Ketua Pengadilan H.A. Pardede yang menangani perkara sengketa tanah suku Tenda dan Kumba di Manggarai-Flores pada bulam Mei 1991 silam merupakan sebuah contoh yang bagus untuk menjelaskan lemahnya institusi hukum negara dalam menangani kasus sengketa, terutama yang terjadi pada masyarakat lokal [Anto Achdiat, "Penyelesaian Sengketa dan Hancurnya Hubungan Kekerabatan: Kasus Sengketa Tanah pada Masyarakat Ruteng di Kabupaten Manggarai, Flores Barat, Nusa Tenggara Timur" dalam T.O. Ihromi (ed), 1993. Antropologi Hukum, Sebuah Bunga Rampai, Jakarta: Obor Indonesia.

2 Secara harafiah istilah "mela sare" terdiri dari dua kata yang memiliki makna hampir sama, yakni "mela" dan "sare" (sareka). "Mela" berarti baik atau menjadi baik kembali, sedangkan "sare" dimaknakan sebagai damai atau berbaik kembali dalam suasana hati yang bersih, tiada dendam dan tiada amarah. Istilah "mela sare" disepadankan dengan istilah "tapan holo" yang terdiri dari dua kata, yakni "tapan" dan "holo". Istilah "tapan" dimaknakan sebagai tambah (menambah), membuat atau memperbaiki kembali, sedangkan "holo" berarti sambung, tersambung, terhubung kembali (termasuk relasi sosial yang terganggu akibat konflik atau sengketa yang dihadapi.
}

membangun kembali relasi sosial di antara para pihak yang bertikai. Masyarakat Lamaholot dalam menyelesaikan kasus sengketa apa pun jenisnya dan melalui institusi peradilan mana pun (baik peradilan lokal maupun peradilan negara), selalu mengupayakannya hingga ke tahapan perdamaian dengan menyelenggarakan ritus adat mela sare (perdamaian). ${ }^{3}$

Berbagai latar tematik sebagaimana diuraikan secara sepintas di atas menjadikan fenomena yang ditampilkan oleh masyarakat Lamaholot ini semakin urgen untuk dikaji lebih jauh untuk menemukan landasan filosofis dan teoretik dari pola-pola peradilan yang dikonstruksikan oleh masyarakat Lamaholot dalam menyelesaikan kasus sengketa secara damai. Secara lebih spesifik, kajian terhadap konstruksi peradilan yang demikian itu akan lebih difokuskan pada praktik penyelesaian kasus kriminal. Fokus kajian yang demikian didasarkan pada pertimbangan bahwa pada dasarnya tradisi perdamaian ini sudah sangat lazim dalam praktik penyelesaian kasus perdata. Bahkan dalam penyelesaian kasus perdata, langkah-langkah perdamaian sangat dianjurkan untuk ditempuh pada saat-saat awal proses berlangsung. Hal ini sangat berbeda dengan proses penyelesaian kasus kriminal (pidana) di mana tradisi perdamaian tidak menjadi titik pijak pertama dan terutama. Oleh karena itu, tradisi penyelesaian kasus kriminal yang dipraktikkan oleh masyarakat Lamaholot akan sangat bermanfaat dalam rangka pengembangan sistem peradilan pidana di Indonesia maupun sistem peradilan pada umumnya.

\section{Permasalahan}

Minimal ada dua permasalahan mendasar yang menjadi fokus kajian ini. Pertama, bagaimana proses perdamaian adat mela sare atau tapan holo itu berlangsung dalam forum-forum peradilan agar kasus kriminal yang ditangani dapat diselesaikan secara damai? Domain yang

Karolus Kopong Medan dkk, 2002 \& 2004, “Pengembangan Pola Peradilan Semi-otonom Menurut Budaya Lokal Lamaholot di Flores, Provinsi Nusa Tenggara Timur", Laporan Riset Unggulan Kemasyarakatan dan Kemanusiaan (RUKK) III, Kerjasama Kantor Kementerian Riset dan Teknologi, LIPI, dan Lemlit Undana, Kupang. 
menjadi fokus tulisan ini terutama mengenai pola-pola konstruksi peradilan berbasis harmoni dalam kerangka budaya Lamaholot.

Kedua, apakah forum-forum peradilan berbasis harmoni yang dikemas dengan memadukan tradisi adat mela sare atau tapan holo itu dapat diandalkan untuk menyelesaikan kasus kriminal secara damai? Persoalan kedua ini paling tidak berfokus pada dua domain utama: (a) keutamaan atau keunggulan dari forum peradilan berbasis harmoni, (b) orientasi yang hendak dicapai oleh forum-forum peradilan tersebut dalam menyelesaikan kasus kriminal.

\section{Hasil dan Pembahasan \\ Basis Harmoni dalam Peradilan: Belajar dari Kearifan Masyarakat lamaholot}

Sekalipun sudah ada kerangka umum yang berlaku secara nasional dan secara unifikatif dituangkan dalam tata aturan hukum tentang sistem peradilan di Indonesia, namun dalam praktiknya masyarakat Lamaholot dapat mengkonstruksikan secara berbeda menurut latar sosiokultural yang dimiliki. Masyarakat Lamaholot tidak saja mengandalkan pola peradilan negara yang disiapkan oleh negara, tetapi justru menampilkan juga pola-pola peradilan versi lain, seperti pola peradilan adat dan pola peradilan campuran (baik campuran antara peradilan adat dengan peradilan negara maupun antara peradilan adat dengan lembaga pemerintahan modern: RT, RW, Dusun, Desa, dan lain sebagainya).

Sekalipun pola peradilan berbasis harmoni ditampilkan beragam, namun pola-pola peradilan tersebut selalu memanfaatkan institusi adat mela sare atau tapan holo (perdamaian) sebagai sarana untuk mendamaikan atau memperbaiki relasi sosial para pihak yang bertikai. ${ }^{4}$ Selama Institusi adat ini belum bekerja maka hubungan atau relasi sosial di antara pihak-pihak yang bertikai belum dipulihkan secara adat karena masih dibatasi oleh "sekat adat" kene-

\footnotetext{
4 Selain institusi adat perdamaian mela sare, institusi soga sumpa (sumpah adat) sebagai sarana penuntut bagi semua pihak yang terlibat dalam proses penyelesaian sengketa untuk menemukan keadilan dan kebenaran yang hakiki). Karolus Kopong Medan, dkk, op cit.
}

tun-bewoten sebagai simbol yang membatasi "para pihak sebagai musuh". ${ }^{5}$

Pertama, mengenai model konstruksi peradilan berbasis harmoni melalui forum adat. Realitas yang dapat ditangkap dari kehidupan hukum pada masyarakat Lamaholot adalah bahwa forum-forum peradilan adat (forum suku dan forum kampung) ternyata masih tetap dipertahankan, sekalipun "peradilan swapraja" dan "peradilan adat" sudah dinyatakan tidak berlaku lagi sejak dikeluarkan UU No. 19/1964 tentang Ketentuan-Ketentuan Pokok Kekuasaan Kehakiman, dan UU No. 13/ 1965 tentang Pengadilan dalam Lingkungan Peradilan Umum dan Mahkamah Agung. ${ }^{6}$

Proses penyelesaian kasus-kasus kriminal melalui forum peradilan adat pada prinsipnya berupaya agar para pihak yang terlibat dalam kasus kriminal, baik sebagai pelaku maupun korban, dapat berdamai dalam suasana persaudaraan (mela sareka atau sare dame). Baik di Adonara, Lembata, Flores Darat maupun di Solor ditemukan tipologi peradilan adat yang hampir mirip, sekalipun di sana sini ada sedikit perbedaan, terutama dalam hal istilah atau ungkapan adat yang digunakan karena perbedaan dialek kebahasaan.

Proses penyelesaian kasus kriminal melalui forum adat dimulai dengan laporan dari masyarakat atau pengaduan dari pihak yang menjadi korban atau keluarganya kepada Belen Suku Onen (pembesar dalam suku, kepala suku), kalau pelaku dan korbannya bersasal dari satu suku atau klen, dan dampak dari kasus kriminal tersebut tidak terlalu luas sehingga bisa ditangani oleh kepala suku dalam lingkup kelompok warga yang masih kecil. Jika pelaku dan korban kasus kriminal berasal dari suku yang

Masyarakat Lamaholot berkeyakinan bahwa apabila sekat pemisah adat kenetun bewotene ini dilanggar maka yang bersangkutan dan seluruh kerabatnya akan mengalami musibah berupa sakit, celaka, dan bahkan meninggal dunia.

6 Penjelasan yang relatif memadai tentang pergeseran kebijakan pemerintah tentang tentang sistem peradilan di Indonesia, yakni Sudikno Mertokusumo, 1983, Sejarah Peradilan dan Perundang-undangannya di Indonesia dan apakah Kemanfaatannya bagi Kita Bangsa Indonesia. Yogyakarta: UGM, Cetakan II; dan R. Tresna, 1957, Peradilan di Indonesia dari Abad ke Abad. AmsterdamJ akarta: W. Versluys N.V, 
berbeda, dan memiliki dampak yang diperkirakan akan mengganggu sendi-sendi kehidupan dalam kampung (lewotana), maka kasus tersebut langsung dibawa ke Kebelen Lewotana (pembesar kampung, kepala kampung). ${ }^{7}$

Pihak Kepala Suku (Kebelen Suku Onen) atau Kepala Kampung (Kebelen Lewotana) dalam proses penanganan kasus kriminal, tidak bertindak sendiri dalam mengambil keputusan, melainkan semua tokoh adat dan tokoh masyarakat dalam kampung dihadirkan untuk bersama-sama mencarikan jalan keluar yang terbaik untuk menyelesaikan kasus tersebut. Selain itu, terdapat pula pihak yang disebut lima lei uhu wanan atau lei raran (mediator adat), yakni pihak yang dipercayakan menjadi mediator antara pelaku dan korban bersama keluarganya masing-masing agar dampak dari kasus ini tidak meluas dan menimbulkan persoalan baru yang lebih rumit.

Untuk mengawali proses penanganan kasus (kriminal) di hadapan sidang suku (sidan suku) yang dipimpin oleh Kepala Suku (Kebelen Suku Onen) maupun di hadapan sidang kampung (sidan lewotana) yang dipimpin oleh Kepala Kampung (Kebelen Lewotana), dilakukan ritual adat bau Iolon ${ }^{8}$ untuk memohon tuntunan dari Dewa Rerawulan Tanaekan, Leluhur (Ama Opo Koda Kewokot) dan seluruh kekuatan Dewa dari seluruh penjuru mata angin agar semua pihak yang terlibat dalam proses itu dapat menyelesaikan kasus ini secara benar dan adil. Semua pihak yang terlibat dalam ritual adat itu - pemimpin sidang, para pihak (pelaku dan korban), dan para saksi - secara bergilir menuangkan sedikit tuak ${ }^{9}$ ke atas tanah seraya mengucapkan

7 Dalam struktur pemerintahan adat Atawatun di Kecamatan Ile Ape misalnya, Kebelen Lewotana yang yang bertugas menangani kasus sengketa, termasuk kasus kriminal adalah para pembesar adat yang terdiri dari Lewo Nimun Tana Alawan, Taran Nekin, Taran Wanan, Kapitan Lake dan Kapitan Wae.

8 Bau Iolon merupakan sebuah bentuk ritual adat Lamaholot untuk mendahulukan, menghadirkan dan menyertakan Dewa Rerawulan Tanaekan dan para leluhur dalam setiap peristiwa adat. Ritual bau Iolon ini biasanya dipadukan dengan upacara pao boe yakni pemerian sesajen bagi Dewa dan leluhur.

9 Terkadang tuak yang dipakai dalam ritual adat bau loIon ini dicampur dengan tanah yang sudah diritualkan secara adat oleh Atamua Rerawulan Alapen (wakil Rerawulan Tanaekan di dunia). Ritual adat bau Iolon ini mantra adat memohon kehadiran Dewa Rerawulan Tanaekan dan Leluhur Ama Opo Koda Kewokot untuk menyaksikan sekaligus menunjukkan kebenaran dan keadilan atas kasus yang sedang ditangani.

Setelah ritual adat bau Iolon, dimulailah pemeriksaan untuk mendapatkan keterangan, baik dari pelaku, korban maupun para saksi. Tidak ada tata cara yang paten dalam pemeriksaan ini seperti yang terjadi dalam proses peradilan modern. Proses yang berlangsung dalam peradilan adat ini, yang paling penting adalah kejelasan informasi yang disampaikan oleh semua pihak, dan berupaya agar persoalan ini tidak menimbulkan semakin rusaknya hubungan kekerabatan dan persaudaraan di antara para pihak (pelaku dan korban) dan masyarakat pada umumnya. J adi, proses penye-lesaian kasus kriminal melalui forum peradilan adat lebih mengutamakan aspek harmonisasi atau keseimbang$\mathrm{an}^{10}$ dalam kehidupan masyarakat secara keseluruhan, bukan semata mengadili dan menghukum para pihak yang terlibat dalam kasus kriminal tersebut.

Sekalipun orientasinya lebih diarahkan kepada terciptanya perdamaian demi harmonisasi atau keseimbangan, namun dalam proses peradilan adat ini pun sampai pada penentuan sanksi bagi pelaku yang terbukti melakukan tindak kriminal yang dituduhkan kepadanya, yang disebut dengan istilah nedhan dei (membayar denda/ kewajiban adat) dan pate helo ele kirin (ganti rugi). Dalam referensi-referensi tertentu kedua bentuk sanksi adat ini disebut dengan istilah "Reaksi adat" atau "reaksi masyarakat adat", yaitu segala reakasi (koreksi) adat terhadap segala tindakan untuk menetralisir pelanggaran hukum, dan bertujuan untuk memulihkan keseimbangan, baik keseimbangan dunia lahir dan dunia gaib, keseimbangan dalam kehidupan masyarakat pada umumnya, keseimbang-

dipimpin pula oleh Atamua Rerawulan Alapen (wakil Dewa Rerawulan Tanaekan di dunia).

10 Orientasi peradilan adat Lamaholot ini sejalan dengan konsep "harmonisasi" atau "keseimbangan" yang dianut oleh masyarakat adat Lamaholot, yakni hikun teti wanan Iali lein lau weran rae uak tukan wai mata sebagaimana diuraikan pada bagian terdahulu. 
an antara kelompok masyarakat dan orang perorangan. ${ }^{11}$

Kedua, pola konstruksi peradilan rekonsiliatif melalui forum negara. Selain peradilan adat, masyarakat juga masih memiliki alaternatif lain untuk menyelesaikan kasus sengketa yang dihadapinya, termasuk kasus-kasus kriminal, yakni forum peradilan negara. Oleh karena masyarakat Lamaholot memiliki dan menjadikan "nilai harmoni" sebagai salah satu unsur penting dalam menjaga keseimbangan dunia sosialnya, maka sekalipun forum yang digunakan adalah forum peradilan negara, masyarakat masih tetap memanfaatkan institusi adat mela sare (institusi adat perdamaian) sebagai jalan keluar untuk tetap menjaga harmonisasi kehidupan sosial.

Menyadari akan karakteristik peradilan negara dalam menangani kasus-kasus kriminal (kasus pidana) memiliki daya paksa dari negara, proses adat perdamaian itu dilakukan secara diam-diam, dan hal ini dipandang sangat fungsional dalam menyelesaikan kasus sengketa pada umumnya secara damai. Dengan demikian, proses rekonsiliasi yang berlangsung dalam wadah peradilan negara telah menciptakan "area gelap", yakni area yang tidak menjadi perhatian utama para penegak hukum formal (penyidik, jaksa, hakim, dan petugas pemasyarakatan). "Area gelap" itu sesungguhnya sengaja diciptakan oleh masyarakat Lamaholot untuk mengatasi ketidak-memadaian institusi peradilan negara.

Pola konstruksi peradilan rekonsiliatif dalam forum negara seperti itu sekaligus mengisyaratkan, bahwa soal diakui atau tidak secara formal oleh negara terhadap proses adat perdamaian yang dilaksanakannya itu, bukan merupakan sesuatu yang penting bagi masyarakat Lamaholot. Bagi mereka, yang paling penting dan terutama adalah terjalinnya kembali relasi sosial para pihak yang berperkara dalam suasana damai. Keterbatasan peradilan negara da-

11 R. Soepomo, 1977, Bab Bab tentang Hukum Adat di Kemudian Hari. Jakarta: Pradnya Paramita, hlm. 115. J uga dalam B. Ter Haar. 1981, Azas-Azas dan Sususnan Hukum Adat., edisi terjemahan oleh K. Ng. Soebakti Poesponoto, Jakarta: Pradnya Paramita, Cet. Ke-6, hlm. 256. lam menangkap rasa keadilan dan kebenaran masyarakat Lamaholot itu pulalah yang terkadang membuat mereka menolak putusan pengadilan negara. ${ }^{12}$ Dalam konteks yang demikian itu, masyarakat Lamaholot tampaknya tidak hanya sekedar memandang kehadiran hukum negara (peradilan negara) sebagai beban, ${ }^{13}$ tetapi mereka pun terus berusaha agar beban budaya yang ditimbulkannya itu tidak terlalu berat. Itulah sebabnya, masyarakat Lamaholot dengan penuh kesadaran berusaha keluar dari "rel-rel" hukum modern dengan mengoptimalkan institusi adat perdamaian mela sare atau tapan holo.

Model ini memperlihatkan, bahwa ketika kepolisian mendapat laporan atau pengaduan dari masyarakat dan/atau korban tentang telah terjadi tindak kriminal, maka sejak saat itu pula perangkat sistem peradilan pidana mulai bekerja. Pihak penyidik kepolisian mulai mencari tahu dan mengumpulkan bukti-bukti termasuk menangkap dan menahan orang yang di duga kuat melakukan tindak kriminal tersebut. Proses yang berlangsung dalam sistem peradilan pidana bergulir terus, mulai dari pemberkasan berita acara pemeriksaan perkara (BAP) dan menyerahkannya kepada Jaksa Penunut Umum (J PU), selanjutnya JPU membuat dakwaan untuk dikirimkan kepada pihak pengadilan untuk disidangkan.

Melalui sidang pengadilan kemudian ditetapkan, apakah orang yang dituduhkan itu terbukti secara sah dan meyakinkan melakukan tindak kriminal atau tidak. Pada setiap tahapan pemeriksaan, bisa saja terjadi dua kemungkinan bagi orang yang disangka atau didakwa, yaitu dibebaskan karena tidak cukup bukti atau

12 Deskripsi yang relatif lengkap mengenai hukum negara (peradilan negara) sebagai "beban budaya" bagi masyarakat tradisional dapat ditemukan dalam Bernard L Tanya, 2000, Beban Budaya Lokal Menghadapi Hukum Negara: Analisis Budaya Atas Kesulitan Sosio-kultural Orang Sabu Menghadapi Regulasi Negara, Disertasi Doktor Ilmu Hukum, Semarang: PDIH Undip.

13 Harus diakui pula bahwa kehadiran hukum negara sebagai konsekuensi logis dari adanya pemerintahan modern memang telah menyebabkan sebagian peran yang dimainkan oleh kebelen suku onen (kepala suku), kebelen Lewotana (kepala Kampung), lembaga adat Demon Pagong di Flores Darat, pemerintahan adat Watun Lewo Pito di lle Ape Lembata, dan lain sebagainya semakin terkikis/ pudar, termasuk perannya dalam menyelesaikan kasus sengketa. 
diproses terus sampai mendapatkan penetapan hukuman dari pengadilan untuk dijalani di Lembaga Pemasya-rakatan atau dikenakan hukuman jenis lain seperti denda, dan lain sebagainya.

Secara formal, klimaks dari proses hukum yang berlangsung melalui sistem peradilan pidana adalah ketika hakim menetapkan putusannya dan dilanjutkan dengan proses eksekusi pelaku untuk menjalani hukuman, baik di Lembaga Pemasyarakatan maupun menj alani hukuman jenis lain. Pihak penyelenggara peradilan pidana tidak mau tahu lagi tentang bagimana kondisi dan keberadaan si pelaku di masyarakat, termasuk bagaimana relasi sosial antara pelaku dengan korban dan lingkungan sosialnya.

Menyadari akan kelemahan pola peradilan negara itu, maka "secara diam-diam" tanpa sepengetahuan pihak penyelenggara peradilan pidana, pihak pelaku dan keluarganya secara tahu dan mau untuk memenuhi kewajiban adat (nedhan dei dan pate ele kirin) dan melaksanakan ritual adat mela sareka atau ritual tapan holo (ritual adat perdamaian) demi menjaga harmonisasi atau keseimbangan di dalam masyarakat. Keseimbangan yang dimaksud adalah keseimbangan sosial secara menyeluruh dalam komunitas Lewotana (kampung) dan komunitas suku, maupun secara personal antar para pihak dan keluarga. Pihak yang mengatur pemenuhan kewajiban adat dan perayaan ritus adat mela sareka atau tapan holo ini adalah pembesar suku dan pembesar lewotana, Ata Molan (Tabib Adat), Atamua Rerawulan Alapen (wakil Dewa Rerawulan Tanaekan di dunia), dan para pihak beserta seluruh keluarganya.

Ketiga, fenomena lain yang menunjukkan kreativitas masyarakat Lamaholot dalam mengkonstruksi model penyelesaian kasus kriminal secara damai adalah "peradilan berbasis harmoni versi campuran". Model ini tampil dalam dua varian model peradilan yang merupakan campuran antara peradilan adat dengan mekanisme penyelesaian oleh pemerintahan modern (RT, RW, Kepala Desa).

Konstruksi yang demikian bisa saja terjadi sebagai konsekuensi logis dari semakin mendominasinya sistem pemerintahan modern sejak diberlakukan undang-undang No. 5 Tahun
1974 tentang Pokok-Pokok Pemerintahan di Daerah. Gambaran tentang pola peradilan campuran ini sekaligus menunjukkan bahwa ternyata sudah ada unsur baru (unsur lain) yang digunakan dalam proses penyelesaian kasus kriminal. Dalam kasus-kasus tertentu aparat pemerintahan desa (modern) seperti: RT (Rukun Tetangga), seperti RW (Rukun Warga), Dusun, Kepala Desa ikut dilibatkan dalam proses penyelesaiannya. Bahkan, di sejumlah desa ditemukan adanya peraturan desa yang mengatur tentang tata cara penyelesaian kasus-kasus sengketa, termasuk kasus-kasus kriminal beserta pedoman penetapan sanksi-sanksi desa.

Hasil temuan sebagaimana dideskripsikan pada bagian-bagian terdahulu memperlihatkan adanya "varian-varian forum penyelesaian kasus kriminal". Tampak bahwa dari penelitian yang dilakukan secara terbatas di kawasan budaya Lamaholot saja, ditemukan adanya keragaman cara yang ditempuh oleh masyarakat Lamaholot untuk menyelesaikan kasus kriminal yang dihadapi. Itu berarti, dapatlah dibayangkan bahwa dalam konteks Indonesia akan tampil begitu beragamnya forum penyelesaian sengketa yang dikonstruksikan oleh masyarakat di seluruh belahan Indonesia dengan mengikuti pola budayanya masing-masing.

Realitas yang demikian membenarkan tesis Satjipto Rahardjo, ${ }^{14}$ bahwa forum peradilan negara yang disiapkan oleh negara bukan satusatunya forum bagi masyarakat untuk menyelesaikan kasus sengketa yang dihadapi. Optik sosio-antropologis justeru memperlihatkan begitu banyak forum yang bisa dipakai oleh masyarakat untuk menemukan keadilan dan kebenaran.

\section{Keutamaan Peradilan berbasis Harmoni}

Pola peradilan berbasis harmoni yang dikonstruksikan oleh masyarakat Lamaholot dengan memadukan institusi adat mela sare daIam penyelesaian kasus kriminal itu sesungguhnya berorientasi kepada upaya untuk membangun harmoni atau keseimbangan dalam konteks yang lebih luas, baik harmonisasi dalam lingkungan sosial secara keseluruhan maupun

14 Satjipto Rahardjo, 1991, IImu Hukum. Bandung: Citra Aditya Bakti, hlm. 281-282. 
harmonisasi secara personal antara para pihak yang bertikai. Bahkan, proses penyelesaian kasus kriminal itu pun memiliki aspek religiustias untuk membangun harmonisasi secara vertikal antara manusia dengan Sang Ilahi. Singkatnya, Institusi adat mela sare merupakan sarana penghubung untuk menghantar para pihak yang bertikai beralih dari dunia penuh konflik menuju dunia penuh bahagia, aman dan damai.

Oleh karena proses rekonsiliasi yang dijalankan oleh masyarakat Lamaholot itu juga secara religius-magis dengan mengikutsertakan Dewa Rerawulan Tanaekan dan para Leluhur Ama Opo Koda Kewokot, maka proses rekonsiliasi yang dilaksanakan itu memiliki daya ikat yang sangat kuat antara para pihak yang bertikai. Kekuatan daya ikat dari proses peradilan berbasis harmoni itu sangat diresapi oleh masyarakat Lamaholot yang menjalaninya, sehingga hubungan sosial di antara mereka pascarekonsiliasi benar-benar berada dalam suasana baru, yaitu suasana penuh bahagia, aman dan damai. Suasana batin dan suasana kehidupan sosial pasca-rekonsiliasi memang sungguh berbeda dengan suasana sebelumnya, karena sudah tidak ada lagi "sekat pemisah" berupa kenetun bewotenen (pemutusan hubungan secara adat) yang melarang para pihak untuk membangun relasi sosial dalam bentuk apapun.

Bagi masyarakat Lamaholot, proses rekonsiliasi merupakan salah satu bagian dari proses penyelesaian sengketa yang sangat menentukan masa depan para pihak. Menyadari akan hal ini, dalam berbagai kasus yang berhasil dihimpun di lokasi penelitian menunjukkan bahwa institusi rekonsiliasi mela sare atau tapan holo itu merupakan bagian dari proses hukum yang dilakukan secara adat. Bahkan, konsep rekonsiliasi yang dipahami oleh masyarakat Lamaholot tidak sekedar rekonsiliasi individual, melainkan juga rekonsiliasi dalam artian yang lebih luas meliputi: berdamai dengan lingkungan sosial (lewotana), berdamai dengan Sang Dewa Rerawulan Tanaekan, dan berdamai dengan Leluhur Ama Opo Koda Kewokot.

Persoalannya sekarang adalah apakah pola-pola peradilan berbasis harmoni yang dikonstruksikan itu mampu membangun relasi sosial para pihak ke arah yang lebih baik? Pertanyaan penuntun ini menuntut untuk dicari tahu lebih jauh tentang bagaimana proses menuju perdamaian yang berlangsung dalam wadah peradilan berbasis harmoni. Hal ini secara tersirat akan menjelaskan tentang bagaimana masyarakat Lamaholot berusaha untuk menata suatu kehidupan dalam dunia yang penuh konflik menuju sebuah dunia baru yang penuh damai melalui wadah peradilan berbasis harmoni.

Ketika suatu kasus kriminal terjadi dan berdampak pada terciptanya situasi sosial yang penuh konflik, maka saluran hukum yang ditempuh adalah bervariasi, baik melalui forum peradilan adat, peradilan negara maupun peradilan campuran. Forum-forum peradilan tersebut, tidak hanya mengadili dan menjatuhkan pidana bagi para pelakunya, melainkan dapat membuka ruang yang lebih luas untuk membangun kembali dunia sosial yang rusak dan menghantar para pihak (pelaku, korban, keluarga) serta masyarakat secara keseluruhan menuju dunia yang penuh bahagia, aman, damai dan sejahtera.

Institusi yang dipakai untuk memperbaiki dunia sosial yang penuh konflik menuju dunia penuh bahagia itu adalah institusi adat perdamaian mela sare atau tapan holo. Tahapan-tahapan ritual adat yang berlangsung dalam institusi adat perdamaian mela sareka itu bolehlah dipandang sebagai "tangga" yang harus digunakan oleh lembaga peradilan untuk menyelesaikan kasus-kasus kriminal secara damai. ${ }^{15}$ Dalam pandangan yang lebih umum "tangga perdamaian" tersebut berfungsi untuk menghubungkan dua dunia dengan kondisi dan situasinya yang amat berbeda atau bertolak belakang. Dunia yang pertama adalah "dunia yang penuh dengan konflik", yakni dunia di mana selalu terjadi pertikaian, peperangan, pembunuhan, penganiayaan, dan kasus-kasus kriminal lainnya. Sebaliknya, dunia yang kedua adalah "dunia yang aman dan damai", yakni dunia di mana masyarakat hidup dengan aman dan

15 Tahapan-tahapan ritual adat tersebut, menurut masyarakat Lamaholot merupakan suatu keharusan untuk dilaksanakan, karena kalau tidak maka relasi sosial di antara para pihak yang bertikai masih tetap terputus (kenetun bewoten). 
damai tanpa ada permusuhan, tanpa ada kekerasan dan perang, tanpa ada penipuan, korupsi, dan lain sebagainya.

Proses ritual adat perdamaian mela sare yang harus dilaksanakan untuk mebangun kembali relasi sosial para pihak adalah pertamatama dimulai dengan melaksanakan ritus adat getun liko petin pepa, yakni tahapan ritual adat untuk mempertegas garis pemisah antara pihak pelaku tindak kriminal dengan pihak korban. Secara adat relasi sosial kedua belah pihak dibatasi, dan sekaligus digunakan oleh kedua belah pihak untuk merenungkan kembali secara lebih tenang tentang kebenaran dari peristiwa itu. Selama masa ini pun pihak mediator adat (lei raran) mulai bekerja untuk mempertemukan kedua belah pihak agar bisa berdamai kembali. Kedua tahapan ritual tersebut merupakan tahapan awal menuju perdamaian (pra-perdamaian).

Apabila usaha mediator adat ini berhasil, maka kedua belah pihak lalu memasuki tahapan ritual adat berikut, yaitu uku loyak gatu gatan untuk merekonstruksi kebenaran melalui pembicaraan terbuka antara kedua belah pihak dengan dipandu oleh Atamua Rerawulan Alapen sebagai wakil Dewa di dunia. Peran Atamua Rerawulan Alapen dalam hal ini sangat besar artinya, terutama untuk menentukan kesalahankesalahan yang dilakukan oleh kedua belah pihak. ${ }^{16}$ Setelah masing-masing pihak mengetahui dan menyadari kesalahan-kesalahannya maka kedua belah pihak biasanya saling memaafkan.

Ritual adat selanjutnya adalah haput ele kirin, yakni menghapus kesalahan-kesalahan yang sudah teridentifikasikan tersebut oleh Atamua Rerawulan Alapen. Ketika segala kesalahan para pihak dihapuskan secara adat, maka dengan sendirinya sudah tidak ada lagi beban adat yang menghalangi para pihak untuk berdamai. Para pihak dengan suasana batin yang bersih dan dengan semangat yang baru mulai memasuki tahapan terakhir dari ritual adat perdamaian mela sare sebagai sarana menuju dunia

16 Dalam menentukan kesalahan-kesalahan para pihak, Atamua Rerawulan Alapen biasanya didampingi atau dibantu oleh seorang Tabib Adat (Ata Molan) yang memiliki kemampuan khusus untuk menentukan kesalahan seseorang. baru yang diidealkan sebagai "dunia penuh aman dan damai". ${ }^{17}$

Sekalipun masih sangat tradisional dan penuh dengan unsur religius-magis, namun apa yang dilakukan oleh masyarakat Lamaholot itu meru-pakan informasi yang sangat berharga dalam menata kembali kelembagaan peradilan di negeri ini ke arah yang lebih baik, terutama bagi masyarakat Lamaholot yang menjadi fokus dari studi ini. Apa yang dilakukan oleh masyarakat Lamaholot itu bolehlah dipandang sebagai bahan permenungan yang bagus bagi para pembuat dan peneyelenggara kebijakan peradilan negara untuk mulai memikirkan kembali orientasi peradilan yang selama ini dianut di Indonesia.

\section{Wawasan Teoretik Peradilan Berbasis Harmo- ni}

Pola-pola penyelesaian kasus kriminal (termasuk juga kasus non-kriminal) yang berorientasi pada penciptaan harmoni sebagaimana dikonstruksikan oleh masyarakat Lamaholot itu sesungguhnya dipraktikkan juga oleh masyarakat lain di Indonesia. Sekalipun pola-pola yang dikembangkan itu berbeda karena disesuaikan dengan konteks sosial dan budaya masyarakat setempat, namun kalau dilacak ide dasar yang ingin diwujudkan maka akan ditemukan adanya orientasi yang sama, yaitu membangun kembali harmonisasi atau keseimbangan.

Hal ini dapat dicermati dari penganutan terhadap nilai dasar "harmoni" oleh masyarakat di daerah lain. Pola pencermatan yang demikian didasarkan pada pertimbangan, bahwa nilai-nilai budaya - termasuk nilai harmoni merupakan aspek kognitif yang membentuk pola pikir dan pola perilaku seseorang atau sekelompok orang dalam kehidupan sehari-hari, Apabila diketahui bahwa masyarakat tersebut memiliki nilai harmonisasi, maka pola-pola yang dipakai dalam menyelesaikan kasus sengketa

\footnotetext{
17 Sebagai simbol para pihak disatukan kembali dalam satu ikatan sosial penuh aman dan damai, dan sekaligus mendeklarasikan kepada masyarakat umum, maka diadakanlah makan dan minum (bua behin) bersama dengan seluruh warga masyarakat.
} 
yang dihadapi pun diyakini akan ikut terpola oleh nilai harmonisasi tersebut. ${ }^{18}$

Beberapa riset yang dilakukan di beberapa daerah di Indonesia menunjukkan bahwa nilai harmonisasi sangat menyemangati proses penyelesaian sengketa pada umumnya. Beberapa di antaranya adalah yang dipraktikkan oleh: (a) masyarakat Bengkalan Madura" yang menempatkan kepala desa sebagai mediator perdamaian; ${ }^{19}$ (b) masyarakat petani dan nelayan di Tuban, Jawa Timur yang lebih memilih bentuk peradilan konsiliasi; ${ }^{20}$ (c) masyarakat Timor (Belu, TTU, dan TTS) juga selalu menerapkan tradisi adat perdamaian hak neter malu dan halan dalam menyelesaikan setiap sengketa; ${ }^{21}$ (d) masyarakat di Flores seperti di Manggarai memiliki tradisi perdamaian hambor, ${ }^{22}$ di Ende Lio dengan institusi adat perdamaian tura ja$\mathrm{ji}^{23}$ (e) masyarakat di pedalaman Jawa juga

18 Kerangka pemikiran yang demikian sejalan dengan pemikiran Barda Nawawi Arief yang memandang tatanan hukum (termasuk tatanan hukum prosedural) dengan tatanan nilai merupakan satu kesatuan. Dalam arti bahwa tatanan nilai semestinya harus mewarnai pembentukan dan penegakan tatanan hulum [Barda Nawawi Arief, Beberapa Aspek Pengembangan IImu Hukum Pidana: Menyongsong Generasi Baru Hukum Pidana Indonesia, Pidato Pengukuhan Guru Besar dalam IImu Hukum, Semarang: Fakultas Hukum Undip, 25 J uni 1994, hlm. 28-30.

19 Mochamad Munir, 1996, Eksistensi Pengadilan Negeri Sebagai Lemabaga Formal untuk Penyelesaian Sengketa dalam Masyarakat: Studi Sosio-hukum yang Berkaitan dengan Penyelesaian Sengketa Tanah di Kabupaten Bengkalan Madura, Disertasi Doktor IImu Hukum, Surabaya: Program Pascasarjana Universitas Airlangga, hlm. 186.

20 Indah Sri Utari, 2004, Makna Sosial Hukum Bagi Masyarakat Petani dan Nelayan di Tuban: Kajian tentang Alasan Sosial dalam Memilih atau Tidak Memilih PengadiIan Sebagai Forum Penyelesaian Sengketa Tanah, Disertasi Doktor IImu Hukum, Semarang: PDIH Universitas Diponegoro, hlm. 234-264.

21 J ohn Kotan \& Rafael R. Tupen, 2002, Kajian Hukum Adat dalam Penyelesaian Masalah Tanah di Nusa Tenggara Timur, Laporan Hasil Studi. Kupang: Kerjasama BAPPEDA NTT \& Laboratorium Hukum FH Undana, hlm. 16-29.

22 Beni Tukan, dkk., 2003, Konflik Tanah Suku di Propinsi Nusa Tenggara Timur: Studi tentang Manajemen Konflik, Laporan Hasil Riset Unggulan Kemasyarakatan dan Kemanusiaan (RUKK) Tahap II, Kupang: Kerjasama Kementerian Riset dan Teknologi - LIPI - Balibangda NTT, hlm. 76-78.

23 Blasius Raja, 2002, Tura Jaji: Perjanjian Adat sebagai Pedoman Kohesif dalam Membina Kehidupan Sosial Masyarakat Suku Lio di Flores, Laporan Hasil Riset Unggulan Kemasyarakatan dan Kemanusiaan (RUKK) III Tahun I, Kupang: Kerjasama Kantor Kementerian Riset dan Teknologi - LIPI - Unika Widya Mandira Kupang, 2939. mengenal pola peradilan "padu" atau "pepadun" dan cukup fungsional pada jaman kerajaan dan masa-masa awal penjajahan Belanda; ${ }^{24}$ dan masih banyak yang lain.

Temuan tersebut memang tidak menunjuk secara tegas tentang tipologi peradilan berbasis harmoni, namun jika dilihat dari aspek substansi atau muatan yang dihasilkan dari proses-proses penyelesaian sengketa, maka tampak bahwa konsep tentang peradilan berbasis harmoni bukan merupakan sesuatu yang khas dan hanya dimiliki oleh masyarakat Lamaholot. Jiwa dan semangat dari peradilan yang sarat dengan nilai harmoni tersebut dapat ditemukan di semua daerah di Indonesia.

Sekalipun terdapat semangat yang sama, namun pola-pola peradilan berbasis harmoni yang dikonstruksikan oleh masyarakat di masing-masing daerah jelas akan berbeda-beda, karena sangat tergantung pada konteks sosial dan pandangan dunia dari masyarakat yang bersangkutan. Konteks sosial dan pandangan dunialah yang membuat pola peradilan berbasis harmoni versi Lamaholot berbeda dengan yang dikonstruksikan oleh masyarakat lain.

Dari pelacakan lebih jauh terhadap tatanan hukum yang dikonstruksikan oleh masyarakat di Jepang misalnya, ternyata orientasi yang ingin dituju dari sebuah proses hukum adalah sama, yakni berusaha membangun kembali harmonisasi atau keseimbangan dalam konteks yang lebih luas. Semangat harmonisasi yang ditampilkan oleh masyarakat J epang dalam tatanan hukumnya itu sesungguhnya disemangati oleh konsep hidup amaeru, yakni konsep hidup yang berusaha untuk merajut kehidupan yang penuh bahagia dalam suasana kebersamaan.

Pada tataran teoretik, data hasil studi yang ditemukan dari masyarakat Lamaholot itu ternyata memiliki seperangkat konsep teoretik yang merupakan dasar bagi peradilan berbasis harmoni, yakni konsep kriminalitas, peradilan (pidana), rekonsiliasi, kebenaran dan keadilan, dan konsep harmonisasi. Apabila sekalian konsep teoretik tersebut dihubung-hubungkan antara satu dengan yang lain, maka akan melahir-

24 Hilman Hadikusuma, 1989, Peradilan di Indonesia. Jakarta: CV. Miswar, hlm. 8-12. 
kan sejumlah proposisi (pernyataan teoretik), yang kebenarannya dapat dipertanggungjawabkan secara ilmiah. Pertama, munculnya tindak kriminal atau kasus sengketa pada umumnya akan mengakibatkan chaos atau ketidakteraturan yang mengganggu keharmonisan kehidupan sosial; kedua, jalinan antara peradilan atau pola-pola penyelesaian sengketa pada umumnya dengan proses rekonsiliasi akan membantu pihak-pihak yang bertikai untuk menghilangkan khaos dan sekaligus menghantar mereka menuju tatanan kehidupan sosial yang harmonis; ketiga, harmonisasi tatanan kehidupan sosial yang diupayakan melalui proses peradilan berbasis harmoni itu tidak hanya dikembangkan atau diusahakan secara individual (antara para pihak), melainkan dalam tatanan kehidupan sosial secara menyeluruh dalam sebuah komunitas; keempat, harmonisasi yang diupayakan melalui peradilan berbasis harmoni dimaksudkan juga untuk memperbaiki kembali sekaligus memperbaharui relasi antara manusia dengan Yang Ilahi; kelima, seluruh proses hukum yang berlangsung dalam forum peradilan berbasis harmoni berada di bawah tuntanan dan kontrol kekuatan sosial (kekuatan duniawi) maupun kekuatan adikodrati (kekuatan Ilahi); keenam, kebenaran, keadilan, dan rekonsiliasi yang diupayakan melalui proses peradilan merupakan kunci bagi para pihak dan masyarakat secara keseluruhan dalam membangun kehidupan sosial yang harmonis; dan ketujuh, harmonisasi kehidupan sosial yang dibangun melalui proses peradilan berbasis harmoni itu tidak hanya dimaksudkan untuk membangun keselarasan secara horisontal dalam kehidupan nyata (kehi-dupan duniawi), melainkan juga membangun keselarasan hubungan secara vertikal dengan Sang Ilahi.

Harmonisasi kehidupan sosial yang dibangun melalui peradilan berbasis harmoni Dalam tataran yang paling abstrak, sesunnggunya diletakkan di atas dasar teoretik yang kokoh yang disebut teori hukum "mela sare", yakni teori hukum yang lebih mengutamakan keselarasan atau keharmonisan dalam tiga dimensi (dimensi individual, sosial dan imanen).
Mencermati karakteristik teori hukum "mela sare" yang menjadi landasan bekerjanya peradilan berbasis harmoni, tampak adanya kesejajarannya dengan teori (hukum) "kosmovision", yakni teori (hukum) yang berorientasi pada keselarasan kosmos secara total. Teori peradilan yang demikian jelas akan menopang proses peradilan yang berusaha untuk membangun keseimbangan kosmos beserta seluruh isinya. Peradilan yang dibangun di atas landasan teori tersebut, tidak hanya memikirkan nasib pelaku atau korban tindak kriminal secara individual, melainkan memikirkan keseimbangan lingkungan sosial secara keseluruhan, dan keselarasan hubungan dengan Sang Ilahi.

Kerangka teoretik yang demikian itu pun tampaknya sejalan dengan pandangan Filsafat Timur pada umumnya yang lebih bersifat sotereologis (sooteria artinya keselamatan). Filsafat Timur lebih menaruh perhatiannya kepada upaya untuk mencapai keselamatan dengan melepaskan diri dari ikatan dunia ini, dan jalan untuk menuju keselamatan itu bersifat religius dan askese. ${ }^{25}$ Pandangan yang seperti itu pulalah yang mungkin mendorong lahirnya pola-pola perilaku ekspresif masyarakat Lamaholot dalam mengkonstruksi pola-pola penyelesaian sengketa dan proses-proses rekonsiliasi yang sarat dengan nilai-nilai religiusitas.

Apabila pandangan sotereologis itu dihubungkan dengan dunia peradilan (pidana), maka dapatlah dikatakan bahwa peradilan yang baik atau peradilan yang benar ialah peradilan yang mampu menyelamatkan. Proses-proses yang berlangsung dalam suatu sistem peradilan (pidana) harus mampu menghantar semua pihak yang terlibat secara langsung dalam proses peradilan pidana (pelaku dan korban beserta keluarganya masing-masing), dan seluruh warga masyarakat secara keseluruhan menuju keselamatan (sooteria). Keselamatan yang diusahakan melalui proses peradilan (pidana) adalah "ke-

25 Hasrat untuk menuju peradilan yang menyelamatkan menyentuh hakikat Filsafat Timur, khususnya Hinduisme dan Buddhisme, yang menekankan bahwa "pengetahuan yang benar adalan jalan menuju keselamatan. Adelbert Snijders, 2006, "Manusia dan Kebenaran: Sebuah Filsafat Pengetahuan. Yogyakarta: Penerbit Kanisius, hlm. 40-45. 
bahagiaan sejati". Kebahagiaan sejati dalam pandangan Buddhisme, misalnya, dapat terwujud ketika seseorang mencapai "Nirvana" (peniadaan atau kekosongan total). Peniadaan atau kekosongan total yang dimaksudkan di sini adalah peniadaan penderitaan-penderitaan, keputusasaan, penyakit, dan kesedihan selama hidup. Melalui meniadaan penderitaan-penderitaan semacam itu maka muncullah kemudian kete-nangan dan kedamaian (absolut). ${ }^{26}$

Memang apa yang berlangsung dalam sebuah proses hukum tidak akan mungkin menggapai kebahagiaan sejati sebagaimana yang diidealkan oleh para penganut Buddhisme, namun dengan berlandaskan pada teori hukum kosmovision, lembaga peradilan semakin menemukan semangatnya untuk memperbarui atau mendekonstruksi orientasinya menuju harmonisasi secara utuh. Kalau selama ini pikiran kalangan yuris hanya terpusat pada upaya-upaya untuk menemukan kebenaran dan keadilan, maka sudah saatnya berpikir lebih maju lagi untuk membangun harmonisasi secara utuh. Dengan demikian, proses-proses rekonsiliasi yang selama ini diupayakan dipandang sebagai bukan bagian dari proses hukum, melainkan merupakan satu kesatuan yang tidak bisa dipisahkan begitu saja dari sebuah proses hukum secara keseluruhan.

Masuknya dimensi imanen atau spiritualitas ke dalam bangunan teori hukum seperti ini mengisyaratkan bahwa sistem atau teori hukum yang sesungguhnya diidealkan tidak lagi bersifat sekuler, melainkan bersifat holistik yang tidak memisahkan hukum dari aspek spiritualitas atau moralitas keagamaan. Karakteristik tatanan hukum yang bersifat holistik itu, oleh Owen Haley, diindetifikasikan sebagai sebuah prinsip fundamental yang membedakan tradisi-tradisi hukum Asia Timur dengan yang berlaku di Eropa. Dari "Kitab Hammurabi" sampai "Hindu Dharmais", misalnya, tersirat bahwa semula undang-undang yang dibuat secara eksplisit mencantumkan "sumber Ilahi" sebagai pedoman bagi para pembuat dan penegak hukum. Demikian pula dalam konsep agama Yahudi juga

26 Adelbert Snij ders, ibid., 2006, hlm. 44-45. tidak memisahkan secara tegas antara Tuhan sebagai pemberi hukum dan hakim sebagai pelaksana hukum, dan dengan demikian hukum itu sendiri merupakan sebuah ekspresi dari norma-norma agama dan sosial yang mengatur hubungan antara Tuhan dengan manusia, dan antara manusia di dalam masyarakat. ${ }^{27}$

Stoic sebagaimana dikutip oleh Schiller menyatakan, bahwa para pembuat hukum Yunani dan romawi kuno telah mengenal sebuah "hukum alam" yang berakar dalam kepercayaan akan adanya agama, dan dari sanalah konsep keadilan muncul sebagai seperangkat standar kejujuran yang berlaku secara universal. Oleh karena itu pulalah almahrum Ulpianus, seorang yurist Romawi, selalu mengingatkan, bahwa "orang yang ingin mempelajari hukum harus pertama-tama mengetahui dari mana nama "ius" (hukum) itu berasal. Sekarang, nama itu diambil dari kata iustitia yang oleh Celsus didefinisikan secara baik sebagai seni dari kebaikan dan kejujuran (ars boni et aequl)". ${ }^{28}$ Bertolak dari pandangan yang demikian itu, maka apa yang diupayakan melalui peradilan berbasis harmoni jelas tidak terlepas dari aspek imanen, karena selalu mendapat tuntunan dari Sang Ilahi.

\section{Penutup : Beberapa Implikasi}

Hasil kajian sebagaimana diuraikan di atas secara langsung maupun tidak langsung berimplikasi kepada kehidupan hukum pada tataran teoretik maupun pada tataran praktis. Pertama, pada tataran teoretik hasil studi ini berimplikasi pada kerangka pemikiran teoretik yang selama ini dikembangkan dalam peradilan pidana yang lebih berorientasi kepada penetapan kesalahan dan penghukuman (pemidanaan). Memang tidak ada salahnya kalau dalam sebuah proses peradilan pidana diorientasikan untuk mencari orang atau kelompok orang guna mempertanggungjawabkan suatu peristiwa pidana yang terjadi, tetapi yang paling penting juga

27 J ohn Owen Haley, 1991, Authority Without Power: Law and J apanese Paradox, New York: Oxford University Press, HIm. 24.

28 Pendapat Stoic tersebut dikutip oleh A. Arthur Schiller, 1978, Roman Law, New York: Mouton Publisher, hlm. 555; J ohn Owen Haley, loc. cit., hlm. 24. 
adalah bagaimana agar relasi sosial dari para pihak yang terlibat dalam kasus kriminal tersebut dapat dipulihkan kembali dalam lingkup sosial yang lebih besar.

Peradilan pidana di Indonesia memang sudah mulai memikirkan masalah perlindungan korban, terutama dalam hal pemberian ganti rugi atau kompensasi, namun relasi sosial dalam konteks yang lebih besar perlu mendapat perhatian serius. Hal ini menjadi penting, karena baik pelaku maupun korban tidak akan pernah menghidarkan diri dari kehidupan sosial dalam komunitasnya. Oleh karena itu, harmonisasi sosial sangat perlu dibangun kembali agar para pihak yang bertikai dapat kembali ke lingkungan sosialnya secara aman dan damai.

Pada tataran teoretik ini pula temuan studi ini secara tidak langsung memperkuat argumentasi para pengeritik teori social defencenya Marc Ancel, yang berusaha memasukan aspek "pemulihan keseimbangan sosial" dalam kebijakan kriminal. Jika dicermati teori social defence yang digagas oleh Marc Ancel lebih mengutamakan kepentingan-kepentingan secara individual dalam lingkup pelaku dan korban tindak kriminal, maka peradilan berbasis harmoni yang dikembangkan ini memiliki landasan pijak yang justru lebih luas, mencakup harmonisasi dalam lingkup kehidupan sosial secara total. Wawasan peradilan berbasis harmoni yang demikian itu sebagai konsekuensi logis dari teori hukum "mela sare" atau kosmovision yang lebih mengedepankan keselarahan dalam sebuah kosmologi sosial.

Kedua, apabila temuan teoretik dalam studi ini ditarik masuk ke dalam ranah praksis maka jelas akan memberikan beberapa implikasi terhadap kebijakan peradilan pada umumnya, terutama berkaitan dengan pola dan prosedur peradilan pidana di Indonesia. Temuan dari studi ini akan merombak atau mendekonstruksi sistem peradilan pada umumnya, terutama sistem peradilan pidana (SPP). Apabila masalah rekonsiliasi dimasukan sebagai bagian integral dari sebuah proses peradilan (pidana), maka diperlukan sebuah tahapan baru dalam sistem peradilan (pidana), yakni tahapan rekon- siliasi untuk membangun kembali relasi sosial para pihak yang bertikai.

Apabila peradilan berbasis harmoni diangkat dan dilembagakan dalam sebuah proses peradilan pada tataran yang lebih luas dalam konteks Indonesia yang sangat beragam aspek sosio-kulturalnya ini, maka langkah itu harus ditunjang pula oleh politik hukum yang bersifat "multi-sentralistik". Politik hukum yang demikian itu akan memungkinkan masing-masing daerah memiliki kebebasan untuk menata dan mengembangkan peradilan rekonsiliatif versi mereka dengan memanfaatkan secara maksimal kearifan-kearifan lokal milik mereka. Implikasi temuan tersebut mengisyaratkan bahwa peranperan adat (termasuk menjalankan kewajiban adat dan perdamaian adat) tidak bisa direduksi begitu saja menjadi peran-peran yang dijalankan oleh aparat penegak hukum formal dalam sistem peradilan pidana. Apabila institusi adat perdamaian mela sare ditarik masuk sebagai bagian dari sistem peradilan (pidana) untuk diterapkan di Lamaholot, maka hal ini akan berkonsekuensi pada keterlibatan fungsionaris adat dalam proses penyelesaian kasus kriminal untuk memfungsionalkan institusi adat perdamaian.

\section{Daftar Pustaka}

Achdiat, Anto. "Penyelesaian Sengketa dan Hancurnya Hubungan Kekerabatan: Kasus Sengketa Tanah pada Masyarakat Ruteng di Kabupaten Manggarai, Flores Barat, Nusa Tenggara Timur" dalam T.O. Ihromi (ed). 1993. Antropologi Hukum, Sebuah Bunga Rampai. J akarta: Obor Indonesia;

Haley, John Owen. 1991. Authority Without Power: Law and J apanese Paradox, New York: Oxford University Press;

Hilman Hadikusuma. 1989. Peradilan di Indonesia. J akarta: CV. Miswar;

Kopong Medan, Karolus, dkk. 2002 \& 2004. Pengembangan Pola Peradilan Semi-otonom Menurut Budaya Lokal Lamaholot di Flores, Provinsi Nusa Tenggara Timur. Laporan Riset Unggulan Kemasyarakatan dan Kemanusiaan (RUKK) III, Kerjasama Kantor Kementerian Riset dan Teknologi, LIPI, dan Lemlit Undana, Kupang;

Kotan, John \& Tupen, Rafael R. 2002. Kajian Hukum Adat dalam Penyelesaian Masalah 
Tanah di Nusa Tenggara Timur. Laporan Hasil Studi. Kupang: Kerjasama BAPPEDA NTT \& Laboratorium Hukum FH Undana;

Mertokusumo, Sudikno, 1983. Sejarah Peradilan dan Perundang-undangannya di Indonesia dan Apakah Kemanfaatannya bagi Kita Bangsa Indonesia. Yogyakarta: UGM, Cetakan II;

Munir, Mochamad. 1996. Eksistensi Pengadilan Negeri Sebagai Lembaga Formal untuk Penyelesaian Sengketa dalam Masyarakat: Studi Sosio-hukum yang Berkaitan dengan Penyelesaian Sengketa Tanah di Kabupaten Bengkalan Madura. Disertasi Doktor IImu Hukum, Surabaya: Program Pascasarjana Universitas Airlangga;

Nawawi Arief, Barda. Beberapa Aspek Pengembangan IImu Hukum Pidana: Menyongsong Generasi Baru Hukum Pidana Indonesia. Pidato Pengukuhan Guru Besar dalam IImu Hukum, Semarang: Fakultas Hukum Undip, 25 J uni 1994;

Rahardjo, Satjipto. IImu Hukum. Bandung: Citra Aditya Bakti, 1991;

Raja, Blasius. 2002. Tura Jaji: Perjanjian Adat sebagai Pedoman Kohesif dalam Membina Kehidupan Sosial Masyarakat Suku Lio di Flores. Laporan Hasil Riset Unggulan Kemasyarakatan dan Kemanusiaan (RUKK) III Tahun I. Kupang: Kerjasama Kantor Kementerian Riset dan Teknologi - LIPI Unika Widya Mandira Kupang;

Schiller, A. Arthur. 1978. Roman Law, New York: Mouton Publisher;
Snij ders, Adelbert. 2006. Manusia dan Kebenaran: Sebuah Filsafat Pengetahuan. Yogyakarta: Penerbit Kanisius;

Soepomo, R. 1977. Bab Bab tentang Hukum Adat di Kemudian Hari. Jakarta: Pradnya Paramita;

Sri Utari, Indah. 2004. Makna Sosial Hukum Bagi Masyarakat Petani dan Nelayan di Tuban: Kajian tentang Alasan Sosial dalam Memilih atau Tidak Memilih Pengadilan Sebagai Forum Penyelesaian Sengketa Tanah. Disertasi Doktor IImu Hukum, Semarang: PDIH Universitas Diponegoro,

Tanya Bernard L. 2000. Beban Budaya Lokal Menghadapi Hukum Negara: Analisis Budaya Atas Kesulitan Sosio-kultural Orang Sabu Menghadapi Regulasi Negara. Disertasi Doktor IImu Hukum, Semarang: PDIH Undip;

Ter Haar. B. 1981. Azas-Azas dan Sususnan Hukum Adat., edisi terjemahan oleh $\mathrm{K}$. Ng. Soebakti Poesponoto, Jakarta: Pradnya Paramita;

Tresna, R. 1957. Peradilan di Indonesia dari Abad ke Abad. Amsterdam-J akarta: W. Versluys N.V;

Tukan, Beni, dkk. 2003 \& 2004. Konflik Tanah Suku di Propinsi Nusa Tenggara Timur: Studi tentang Manajemen Konflik. Laporan Hasil Riset Unggulan Kemasyarakatan dan Kemanusiaan (RUKK) Tahap II \& III, Kupang: Kerjasama Kementerian Riset dan Teknologi - LIPI - Balibangda NTT. 